\title{
Cross-Examining Socrates: A Defense of the Interlocutors in Plato's Early Dialogues
}

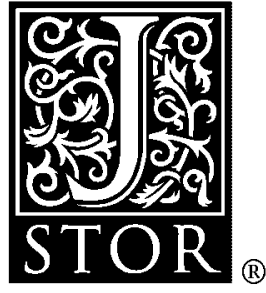

\author{
Review Author[s]: \\ Jyl Gentzler
}

The Philosophical Review, Vol. 110, No. 4 (Oct., 2001), 587-590.

Stable URL:

http://links.jstor.org/sici?sici=0031-8108\%28200110\%29110\%3A4\%3C587\%3ACSADOT\%3E2.0.CO\%3B2-9

The Philosophical Review is currently published by Cornell University.

Your use of the JSTOR archive indicates your acceptance of JSTOR's Terms and Conditions of Use, available at http://www.jstor.org/about/terms.html. JSTOR's Terms and Conditions of Use provides, in part, that unless you have obtained prior permission, you may not download an entire issue of a journal or multiple copies of articles, and you may use content in the JSTOR archive only for your personal, non-commercial use.

Please contact the publisher regarding any further use of this work. Publisher contact information may be obtained at http://www.jstor.org/journals/sageschool.html.

Each copy of any part of a JSTOR transmission must contain the same copyright notice that appears on the screen or printed page of such transmission.

JSTOR is an independent not-for-profit organization dedicated to creating and preserving a digital archive of scholarly journals. For more information regarding JSTOR, please contact support@jstor.org. 


\section{CROSS-EXAMINING SOCRATES: A DEFENSE OF THE INTERLOCUTORS IN PLATO'S EARLY DIALOGUES. By John Beversluis. Cambridge: Cambridge University Press, 2000. Pp. xii, 416}

In Plato's early dialogues, we witness a character named "Socrates" in philosophical action. Simply by asking his interlocutors why they are doing what they do, Socrates reveals how their deepest convictions lack adequate rational grounding. The worry that their own convictions are equally unjustified has inspired many readers of Plato's early dialogues to attempt to correct their own epistemic shortcomings by engaging in further philosophical inquiry. However, it is not obvious that Socrates' own interlocutors in the dialogues are similarly moved by his questions to live a more examined life. For some people, Socrates' apparent failure to convert his own interlocutors to a life of philosophical examination requires an explanation. Typically, scholars put the blame on Socrates' interlocutors: even the best philosophers cannot inspire students who are morally bankrupt and intellectually obtuse.

In Cross-Examining Socrates: A Defense of the Interlocutors in Plato's Early Dialogues, John Beversluis attempts to set the record straight. Through a careful examination of nearly every turn in every Socratic conversation represented in Plato's early dialogues, Beversluis helps us to look again at the characters we have learned to dismiss. For example, as Beversluis persuasively argues, “Crito's loyalty, selflessness, and remarkable capacity for unconditional friendship do not bespeak shallowness and superficiality" (74). Euthyphro's own stand with regard to his father's role in a servant's death is far from unprincipled: indeed, as Beversluis points out, his position that we are obligated to insure that all wrongdoers, even family members, are justly punished is very similar to a position that Socrates takes in the Gorgias (167). To the extent that Beversluis forces us to reconsider our simplistic assessments of the character, intellect, and philosophical positions of Socrates' interlocutors, his rereading of the early dialogues is a valuable contribution.

However, Beversluis's revision of "the standard view" of Socrates and his interlocutors does not end with a sympathetic portrayal of Socrates' interlocutors. It seems that someone has to be blamed for Socrates' inability to convert his interlocutors to philosophy. If it is not his interlocutors' fault that they are unmoved to reexamine their lives, then Socrates must be to blame. According to Beversluis, Socrates fails to persuade his interlocutors to reexamine their lives, not because his interlocutors are morally and intellectually limited, but because Socrates never attempted to achieve such a lofty goal in the first place $(36,39,110,158,169,231,243,244,275)$. Not only does Socrates frequently offer bad arguments against his interlocutors' positions-a fact that many admirers of Socrates reluctantly admit-but more significantly, Socrates never 
really intended to provide compelling arguments in the first place. Indeed, according to Beversluis, Socrates often deliberately misrepresents his interlocutors' views $(207,231,313,314)$ on the rare occasions on which he bothers to figure out what these views really are $(55,176)$. The character that many regard as the paradigm philosopher-as a person whose entire life was devoted to the pursuit of truth and to the moral improvement of himself and his contemporaries-turns out, on Beversluis's view, to be the anti-philosopher, a person entirely indifferent to truth and goodness, who more often than not intended to confuse his fellow Athenians if this confusion led them to utter contradictory remarks $(158,169,176,180,231,243)$.

I doubt that Beversluis's revisionist portrait of the character of Socrates is any more accurate than the dismissive portrayals of Socrates' interlocutors to which Beversluis rightly objects. In fact, Beversluis himself cannot consistently endorse this account of Socrates' goals without accusing Plato of terrible incompetence. For, according to Beversluis, Plato's dialogues "are not transcriptions of actual conversations which preserve what these interlocutors actually said, but fictionalized dramatic works of art in which Plato can make them say whatever he wants them to say" (311 n. 38; see also 12). Beversluis detects in Plato's early dialogues a significant conflict between what Socrates says that he is doing and what he actually does: Socrates says that he cares for the souls of his fellow Athenians, but, according to Beversluis, he treats them very shabbily. Beversluis explains Socrates' apparent bad behavior by attributing to him base goals. In order to explain the discrepancy between these base goals and Socrates' lofty announced purposes, Beversluis accuses Socrates of dishonesty $(36,37,102,168,169,171,273)$. If Beversluis is right in his assessment of Socrates' character on the basis of the evidence that he cites, then either Plato agreed with this assessment, or he simply failed to notice a major inconsistency in his portrayal of Socrates' behavior and words.

It is surprising, then, that Beversluis does not claim that Plato shares his assessment of Socrates' character. In fact, according to Beversluis,

the standard picture derives ultimately from Plato, and its proponents read the early dialogues exactly as he intended them to be read.... Like proponents of the standard picture, Platogreatly overestimates the arguments he puts into the mouth of Socrates and he greatly underestimates the objections he puts into the mouth of the interlocutors. (13)

However, on Beversluis's view, Socrates does not merely offer occasional unsound arguments or misrepresent the views of his interlocutors: he does so deliberately, dishonestly, and consistently.

[Socrates'] announced goal is at once noble and puzzling: noble, because it bespeaks a deep moral seriousness; puzzling, because it is (for the most part) a misdescription of his actual goal-which is not to improve anyone, but simply to win arguments (36). 
But it is hard to believe that a character in a work of fiction could do anything deliberately or dishonestly without the minimally competent creator of this character being at least dimly aware of what is going on.

Moreover, Beversluis's appeal to Socrates' secret and base goals to explain his failure to persuade his interlocutors to live a more examined life rests uncomfortably with an insight that he attributes to Plato about the limitations of philosophical arguments. In the final two chapters of Cross-Examining Socrates, Beversluis attempts to explain why Plato "abandoned the Socratic elenchus" in his transitional and middle dialogues. According to Beversluis, Plato no longer has Socrates cross-examine every person he happens to meet, because Plato eventually concluded that some people will fail to be persuaded by even the most compelling of rational arguments.

Initially enamored of the Socratic elenchus, Plato came to have grave doubts about it and eventually abandoned it because he had come to believe that the self revealed in a person's beliefs-even in his sincerely held beliefs-is not the deepest self. In short, by the time he wrote the Gorgias, Plato had come to recognize that 'peirastic' argumentation-in which the interlocutor is refuted 'from his own beliefs' - is much more problematic than Socrates (and perhaps he himself) had originally supposed. ... Callicles' recalcitrance is not traceable to his lack of knowledge or to his inability to follow an argument, but to his 'false loves.' His problem is not lack of understanding, but resistance to things understood. (369)

However, this account of Plato's new insight into the limitations of rational argument would be entirely unmotivated if Beversluis's initial account of Socrates' failure to persuade his interlocutors is correct. According to Beversluis, in the early dialogues, Socrates is unsuccessful at persuading his interlocutors to take up a more examined life because he deliberately offers his interlocutors bad arguments against positions that they never held. Beversluis remains officially agnostic on the question whether Plato himself saw the flaws in Socrates' arguments in the early dialogues $(42,371)$. But either Plato saw the flaws in Socrates' arguments or he did not. It is impossible to believe that Plato failed to notice what his own characters were able to see. Yet, if Beversluis's initial explanation of Socrates' failure to persuade his interlocutors is correct, they must have had some insight into the limitations of his arguments: otherwise, they would have been persuaded by them. However, if Plato himself appreciated what Beversluis regards as the blatant and deliberate flaws in Socrates' arguments, then Plato is not entitled to draw the conclusions about the limitations of rational argumentation that Beversluis attributes to him in the Gorgias. For according to Beversluis's account of what is going on in the early dialogues, "peirastic" argumentation, that is, the refutation of one's interlocutors "from their own beliefs," was never put to any test, much less to a fair test, in the early dialogues.

My own view, for which I cannot argue here, is that Socrates' behavior provides us with no reason to attribute to the character Socrates anything other 
than the lofty goals that he announces. ${ }^{1}$ But if we reject Beversluis' negative portrayal of Socrates' goals and practice, then, how can we explain Socrates' apparent failure to persuade his interlocutors to lead a more examined life? I myself am not convinced that the puzzle of Socrates' failure to have a positive impact on his interlocutors' lives is a genuine one. It is true that in the early dialogues we do not witness anyone undergoing a significant change of life goals during the course of his conversation with Socrates. Yet, we simply do not know what long-term effects the words of the fictional Socrates had on his fictional interlocutors. The character Nicias attests eloquently to the impact that Socrates has had on his own life and on that of others (La. 187e6-188a3), and I see no reason to doubt his fictional sincerity.

JYL GENTZLER

\section{Amherst College}

'Even Socrates' occasional sophistic behavior is compatible with these goals, or so I argue in "Socrates as Mob Orator: The Sophistic Cross-Examination of Callicles in the Gorgias," Ancient Philosophy 15(1995): 17-43.

The Philosophical Review, Vol. 110, No. 4 (October 2001)

SOCRATIC WISDOM: THE MODEL OF KNOWLEDGE IN PLATO'S EARLY DIALOGUES. By Hugh H. Benson. New York: Oxford University Press, 2000. Pp. ix, 292.

Socrates expresses at least some interest in the knowledge of knowledge as an ability "to divide things and say that one is knowledge and the other is not knowledge" ( $C h$. 170a6-8). If Hugh Benson's characteristically lucid and careful book succeeds in its portrayal of Socrates as epistemologist, then the Charmides text is perhaps more optimistic than is often conceded. ${ }^{1}$ For unlike Gregory Vlastos's Socrates, who was "no epistemologist," Benson's promises "a philosophically complex, fundamentally coherent, and remarkably influential model of knowledge," a model Socrates arrives at, at least in part, by means of a reflective epistemological perspective (6).

The book is divided into three main sections. Part 1 outlines the aims and structure of the Socratic method of examination. Benson identifies eight distinct aims of the Socratic elenchus, ranging from the testing of an interlocutor's claim to wisdom to the ultimate goal of acquiring moral knowledge. The "problem of the elenchus" arises when Socrates and his interlocutors seem to reject a

\footnotetext{
${ }^{1}$ See, for example, R. Ketchum, "Plato on the Uselessness of Epistemology: Charmides 166e-172a," Apeiron 24 (1991): 81-98; and G. Vlastos, Socrates, Ironist and Moral Philosopher (Ithaca: Cornell University Press, 1991), 47-48 n. 12.
} 